Vol. 1 No. 2, September 2020

P-ISSN: 2746-0967, E-ISSN: 2721-656X

\title{
Faktor Penyebab Cyberbullying yang Dilakukan oleh Remaja di Kota Yogyakarta
}

Febrizal Antama1, Mukhtar Zuhdy², Heri Purwanto ${ }^{3}$

Fakultas Hukum Universitas Muhammadiyah Yogyakarta, E-mail: febrizal.antama.2016@law.umy.ac.id, ${ }^{1}$ mukhtarzuhdi@umy.ac.id, ${ }^{2}{ }^{2}$ heripurwanto@umy.ac.id ${ }^{3}$

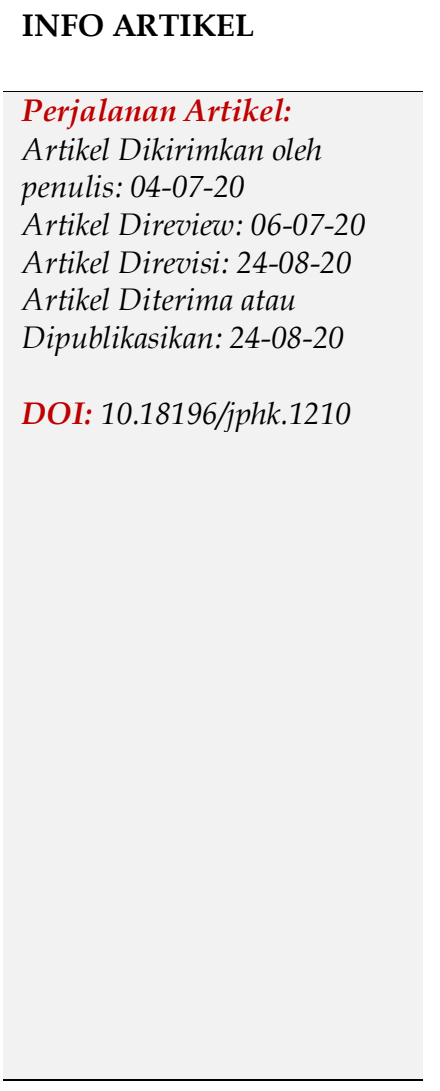

\begin{abstract}
ABSTRAK
Penelitian ini dilakukan untuk mengetahui faktor penyebab terjadinya cyberbullying di Kota Yogyakarta. Jaringan internet berupa media sosial, game online, dan media komunikasi digital lainnya dewasa ini telah menjadi fasilitas bagi terjadinya cyberbullying yang dilakukan oleh remaja di Kota Yogyakarta. Kasus cyberbullying yang dilakukan oleh remaja terus meningkat setiap tahunnya. Maka penting kiranya untuk mengetahui faktor penyebab remaja melakukan cyberbullying. Sehingga diharapkan dengan mengetahui faktor penyebab yang memengaruhi remaja melakukan cyberbullying, kita dapat mengetahui kebijakan kriminal (criminal policy) yang tepat guna memberantas cyberbullying secara lebih efektif. Penelitian yuridis empiris ini menggunakan sumber data primer dan sekunder. Hasil penelitian ini menunjukan bahwa faktor yang menyebabkan remaja melakukan cyberbullying di Kota Yogyakarta antara lain: pesatnya perkembangan teknologi, ketidaktahuan remaja akan risiko hukum, perilaku remaja yang suka meniru, serta telah melemahnya kontrol sosial.
\end{abstract}

Kata Kunci: Criminal Policy, Cyberbullying, Remaja.

\section{Pendahuluan}

Hukum selalu berkembang seiring dengan berkembangnya masyarakat, sebab law as a tool of social engineering (hukum merupakan alat rekayasa sosial). Hukum selalu digunakan sebagai sarana pembaharuan, sebab laju modernisasi yang cepat membuat hukum pun harus mengikuti perkembangan yang ada. Hal ini dilakukan semata-mata dalam rangka melindungi kepentingan masyarakat. Sejatinya telah terdapat UndangUndang Nomor 11 Tahun 2008 Tentang Informasi Dan Transaksi Elektronik jo UndangUndang Nomor 19 Tahun 2016 Tentang Informasi Dan Transaksi Elektronik, yang mengatur terkait penghinaan dan pencemaran nama baik melalui media elektronik. Meskipun telah terdapat pengaturannya, namun pada kenyataannya cyberbullying di 
Indonesia tidak mengalami penurunan, justru terus meningkat dengan laju yang signifikan.

Menurut survei yang dilakukan oleh Asosiasi Penyelenggara Jasa Internet Indonesia (APJII), pengguna aktif internet di Indonesia sebanyak 143,26 juta jiwa dari total 262 juta jiwa penduduk Indonesia. Artinya sebesar $64 \%$ orang Indonesia sudah menggunakan internet. Dari jumlah pengguna internet tersebut, sebesar $80 \%$ adalah remaja berusia 13-18 tahun. ${ }^{1}$ Angka tersebut terbilang sangat tinggi, sebab Indonesia adalah negara dengan pengguna internet terbanyak ke-9 dari 214 negara di dunia. ${ }^{2}$

Satu diantara aplikasi dalam jaringan internet yang paling sering diakses adalah media sosial. Menurut Asosiasi Penyelenggara Jasa Internet Indonesia (APJII), ada 91\% pengguna internet yang mengakses media sosial. ${ }^{3}$ Melalui media sosial setiap orang dapat berinteraksi dan berbagi informasi tanpa harus bertatap muka. Meskipun media sosial dan aplikasi dalam jaringan internet lainnya telah membantu banyak hal bagi penggunanya, akan tetapi ternyata media sosial juga memiliki sifat yang merusak.

Sejalan dengan masifnya penggunaan internet, telah muncul kejahatan baru yang kemudian disebut sebagai cyber crime atau kejahatan siber. Cyber crime atau kejahatan siber merupakan salah satu kejahatan baru yang menggunakan media elektronik atau internet dan terus mengalami perkembangan mulai dari modus maupun ragam kejahatannya. ${ }^{4}$ Salah satu jenis cyber crime adalah cyberbullying. Cyberbullying sejatinya serupa dengan bullying yang dilakukan seacara tradisional, perbedaannya cyberbullying menggunakan sarana teknologi digital atau internet. ${ }^{5}$

Istilah cyberbullying merupakan sesuatu yang baru di tengah masyarakat, meskipun demikian cyberbullying mulai mengkhawatirkan, sebab menurut data dari Komisi Perlindungan Anak Indonesia, jumlah kasus cyberbullying terus meningkat dari tahun ketahun. Pada tahun 2016, sebanyak 56 menjadi pelaku cyberbullying, kemudian pada tahun 2017, meningkat menjadi 73 kasus, dan di tahun 2018, jumlahnya melonjak menjadi 117 kasus. Data anak yang menjadi korban akibat cyberbullying pada tahun 2016 sebanyak 34 kasus, naik menjadi 55 kasus di tahun 2017, dan di tahun 2018 meningkat secara signifikan menjadi 109 kasus. $^{6}$

\footnotetext{
${ }^{1}$ Asosiasi Penyelenggara Jasa Internet Indonesia (APJII). (2019). Laporan Survei Penetrasi \& Profil Prilaku Pengguna Internet Indonesia. Polling Indonesia, April, 2019, hlm. 7.

2Penyusun Wikipedia, "Negara Menurut Jumlah Pengguna Internet", 17 Oktober 2019, https://id.wikipedia.org/wiki/Daftar_negara_menurut_jumlah_pengguna_Internet, (20.08).

${ }^{3}$ Asosiasi Penyelenggara Jasa Internet Indonesia (APJII), Op. Cit., hlm. 20.

${ }^{4}$ Maskun. (2014). Kejahatan Siber (Cyber Crime): Suatu Pengantar. Jakarta: Prenada Media Group, hlm. 47-48.

${ }^{5}$ Richard Donegan. (2012). Bullying and Cyberbullying: History, Statistics, Law, Prevention and Analysis. The Elon Journal of Undergraduate Research in Communications, Vol.1, No.3, hlm. 34.

${ }^{6}$ Reno Mardina. (2019). Kekerasan Terhadap Anak dan Remaja. Infodatin, Juni, 2019, hlm. 6-7.
} 
Penulis fokus pada cyberbullying yang dilakukan oleh remaja di Kota Yogyakarta, yang menempati urutan kedua di Indonesia sebagai daerah pengguna internet terbanyak. Jumlah keseluruhan pengguna internet di Yogyakarta adalah sebesar 73,8\% dari total jumlah penduduk ${ }^{7}$. Selain pertimbangan yang lainnya yaitu banyaknya jumlah pelajar, tingginya angka kenakalan remaja, serta latar belakang sosial yang beraneka ragam, sehingga Kota Yogyakarta potensial dipilih sebagai lokasi penelitian.

Cyberbullying telah menjadi realita di tengah masyarakat, maka mengetahui faktor yang menyebabkan remaja di Kota Yogyakarta melakukan cyberbullying menjadi sangat penting untuk rekomendasi bagi pengambil kebijakan dalam menentukan kebijakan kriminal (criminal policy) baik melalui sarana penal maupun sarana non-penal yang tepat dan dapat dipergunakan untuk memberantas cyberbullying secara efektif. Kebijakan kriminal (criminal policy) sangat penting, karena kebijakan kriminal (criminal policy) merupakan suatu usaha rasional dari masyarakat serta menempati posisi strategis dalam menanggulangi kenakalan remaja. ${ }^{8}$

\section{Metodologi}

\subsection{Jenis Penelitian}

Penelitian ini menggunakan jenis penelitian yuridis empiris. Penelitian empiris penting untuk dilakukan, sebab ahli hukum dan pembuat kebijakan harus mampu memahami secara utuh kondisi dan situasi sosial kemasyarakatan di mana hukum itu diterapkan, sehingga diharapkan mampu menciptakan nilai guna ilmu hukum bagi masyarakat. ${ }^{9}$

\subsection{Sumber Data}

Adapun sumber data yang digunakan dalam penelitian ini antara lain:

\subsubsection{Data Primer}

Data primer adalah data yang diperoleh secara langsung dari masyarakat (mengenai perilakunya). ${ }^{10}$ Penulis memperoleh data atau informasi langsung dengan menggunakan instrumen yang telah ditetapkan. Data primer dikumpulkan oleh penulis untuk menjawab pertanyaan-pertanyaan penelitian. Data primer dalam penelitian ini berupa fakta-fakta yang diperoleh langsung dari Polda DIY, Polresta Yogyakarta, Yayasan Lembaga Perlindungan Anak Daerah Istimewa Yogyakarta, Balai Pemasyarakatan Kelas I Yogyakarta, dan Balai Perlindungan dan Rehabilitasi Sosial Remaja Yogyakarta (Jalan Merapi, Beran, Tridadi, Sleman). Selain itu data

\footnotetext{
${ }^{7}$ Asosiasi Penyelenggara Jasa Internet Indonesia (APJII), op.cit., hlm.14.

${ }^{8}$ Dey Ravena, Kristian. (2017). Kebijakan Kriminal (Criminal Policy). Jakarta: Kencana, hlm. vi.

${ }^{9}$ Mukti Fajar dan Yulianto Achmad. (2017). Dualisme Penelitian Hukum Normatif \& Empiris. Yogyakarta: Pustaka Pelajar, hlm. 44-45.

${ }^{10}$ Soerjono Soekanto. (1982). Pengantar Penelitian Hukum. Jakarta: UI Press, hlm. 51.
} 
primer juga penulis peroleh dari angket atau kuesior kepada pelajar SMA Negeri 7 Yogyakarta.

\subsubsection{Data Sekunder}

Adapun data sekunder atau bahan hukum dalam penelitian hukum dikelompokkan menjadi beberapa macam, antara lain:

a. Bahan hukum primer yang digunakan dalam penelitian ini antara lain:

1) Kitab Undang-Undang Hukum Pidana (KUHP);

2) Undang-Undang Nomor 2 Tahun 2002 Tentang Kepolisian;

3) Undang-Undang Nomor 23 Tahun 2002 Tentang Perlindungan Anak jo Undang-Undang Nomor 35 Tahun 2014 Tentang Perubahan Atas Undang-Undang Nomor 23 Tahun 2002 Tentang Perlindungan Anak;

4) Undang-Undang Nomor 11 Tahun 2008 Tentang Informasi dan Transaksi Elektronik jo Undang-Undang Nomor 19 Tahun 2016 Tentang Perubahan Atas Undang-Undang Nomor 11 Tahun 2008 Tentang Informasi dan Transaksi Elektronik;

5) Undang-Undang Nomor 11 Tahun 2012 Tentang Sistem Peradilan Pidana Anak.

b. Bahan hukum sekunder yang digunakan dalam penelitian ini adalah bukubuku, makalah, artikel, serta tulisan ilmiah lainnya yang merupakan hasil karya kalangan hukum yang berkaitan dengan penelitian.

c. Bahan hukum tersier yang digunakan dalam penelitian ini adalah kamus hukum, ensiklopedi, dan lainnya.

d. Bahan non-hukum yang digunakan dalam penelitian ini menggunakan bahan non-hukum berupa literatur yang berasal dari ilmu kriminologi, ilmu psikologi, sosiologi, dan biologi.

\subsection{Lokasi Penelitian}

Lokasi Penelitian ini dilakukan di Kota Yogyakarta, meliputi:
a. Polda DIY;
b. Polresta Yogyakarta;
c. Yayasan Lembaga Perlindungan Anak Daerah Istimewa Yogyakarta;
d. Balai Pemasyarakatan Kelas I Yogyakarta;
e. Balai Perlindungan dan Rehabilitasi Sosial Remaja Yogyakarta (Jalan Merapi, Beran, Tridadi, Sleman);
f. SMA Negeri 7 Yogyakarta. 


\subsection{Populasi dan Cara Pengambilan Sampel}

Populasi adalah seluruh objek atau seluruh individu yang akan diteliti. ${ }^{11}$ Populasi pada penelitian ini adalah 150 remaja dalam rentang usia 15 tahun sampai 17 tahun di SMA Negeri 7 Yogyakarta serta anak yang berkonflik dengan hukum pada Balai Perlindungan dan Rehabilitasi Sosial Remaja Yogyakarta. Sampel yang digunakan dalam penelitian ini adalah non random sampling, yaitu suatu cara menentukan sampel di mana peneliti telah menentukan sendiri sampel dalam penelitiannya. Teknik Sampel yang digunakan oleh peneliti dalam penelitian ini adalah purposive sampling, yaitu penarikan sampel yang berdasarkan atas suatu tujuan tertentu serta harus didasarkan pada ciri-ciri, sifat-sifat atau karakteristik tertentu yang merupakan ciri-ciri utama populasi. $^{12}$

\subsection{Narasumber}

Adapun narasumber dalam penelitian ini antara lain:

a. Ibu Lidwina Esti Wulandari selaku Ps. Panit 1 Subdit IV Ditreskrimum pada Polda DIY;

b. Bapak Safpe Tambatua Sinaga selaku Panit Ditreskrimsus pada Polda DIY;

c. Bapak Nur Fauzan selaku Ps. Kasubnid IV Direktorat Reserse Kriminal pada Polresta Yogyakarta;

d. Bapak Alyu Herbenu dan Bapak Mujianto, selaku anggota BA Tibmas;

e. Bapak Pranawa selaku Koordinator Devisi Layanan Hukum Yayasan Lembaga Perlindungan Anak Daerah Istimewa Yogyakarta;

f. Ibu Wine Safitri selaku Kasubsi Bimbingan Kemasyarakatan Anak.

\subsection{Responden}

Responden adalah seseorang yang akan memberikan respons terhadap pertanyaan yang diajukan oleh peneliti. Responden selalu dibutuhkan dalam penelitian empiris, sebab responden ada di masyarakat di mana penelitian itu dilakukan. ${ }^{13}$ Adapun responden dari penelitian ini adalah remaja 50 siswa-siswi di SMA Negeri 7 Yogakarta.

\subsection{Teknik dan Alat Pengumpulan Data}

Data primer dikumpulkan melalui studi lapangan ${ }^{14}$, dilakukan dengan wawancara yang dipandu oleh kuesioner terstruktur. Wawancara ditujukan kepada narasumber, sedangkan kuesioner ditujukan kepada 50 responden. Kuisioner dibuat secara terstruktur dalam bentuk pertanyaan pilihan berganda (multiple choice questions) ditujukan kepada siswa-siswi SMA Negeri 7 Yogyakarta dalam rentang usia 15 tahun sampai 17 tahun di Kota Yogyakarta.

\footnotetext{
${ }^{11}$ Ronny Hanitijo Soemitro. (1995). Metodologi Penelitian Hukum dan Jurimetri. Jakarta:Ghalia Indonesia, hlm. 44.

${ }^{12}$ Ibid., hlm. 51.

${ }^{13}$ Mukti Fajar dan Yulianto Achmad, op. cit., hlm. 174.

${ }^{14}$ Ibid., hlm. 98.
} 


\subsection{Analisis Data}

Analisis data yang digunakan dalam penelitian ini adalah analisis yang bersifat deskriptif untuk memberikan gambaran atau pemaparan atas subjek dan objek penelitian sebagaimana hasil penelitian. Pendekatan yang dilakukan dalam penelitian ini adalah pendekatan kualitatif yaitu suatu cara analisis hasil penelitian berdasarkan mutu yang merupakan kumpulan data yang dilakukan baik secara tertulis maupun lisan serta tingkah laku yang nyata yang diteliti dan dipelajari sebagai sesuatu yang utuh. ${ }^{15}$

\section{Analisis dan Hasil}

Merebaknya cyberbullying merupakan konsekuensi dari perkembangan teknologi yang semakin pesat. cyberbullying telah merebak dan banyak dilakukan oleh remaja di Indonesia, tak terkecuali di Kota Yogyakarta. Agar mendapatkan hasil penelitian yang komprehensif, penulis melakukan penelitian di berbagai tempat di Daerah Istimewa Yogyakarta. Setelah melakukan penelitian, penulis memperoleh data terkait kriminalitas cyberbullying dari berbagai institusi, seperti Polda DIY, Polresta Kota Yogyakarta, dan Yayasan Lembaga Perlindungan Anak DIY.

Alasan mengapa penulis melakukan penelitian di berbagai institusi adalah karena kasus cyberbullying yang dilakukan oleh remaja di Kota Yogyakarta ternyata tidak melulu dilaporkan pada satu institusi saja, namun tersebar secara sporadis di berbagai institusi, bahkan dalam satu institusi, kasus cyberbullying pun tersebar ke beberapa direktorat. Sehingga akan penulis paparkan jumlah kasus cyberbullying berdasarkan masing-masing institusi. Agar lebih jelas, akan penulis paparkan dalam bentuk tabel sebagai berikut:

\subsection{Jumlah Kasus Cyberbullying di Kota Yogyakarta}

Tabel 1 Kasus Cyberbullying di Kota Yogyakarta

\begin{tabular}{||c|c||c|c|}
\hline No & Usia Pelaku & Frekuensi & Presentasi \\
\hline \hline 1. & Polda DIY & 4 & $40 \%$ \\
\hline \hline 2. & Polresta Kota Yogyakarta & 2 & $20 \%$ \\
\hline 3. & $\begin{array}{c}\text { Yayasan Lembaga Perlindungan } \\
\text { Anak DIY }\end{array}$ & 4 & $40 \%$ \\
\hline \hline \multicolumn{2}{|c|}{ Jumlah } & 10 & $100 \%$ \\
\hline
\end{tabular}

Sumber: Data primer, diperoleh dari Polda DIY, Polresta Kota Yogyakarta, dan Yayasan Lembaga Perlindungan Anak DIY pada tanggal 2 Desember 2019.

${ }^{15}$ Mukti Fajar dan Yulianto Achmad, op. cit., hlm. 183-192. 
Berdasarkan data di atas, terlihat jelas bahwa kasus cyberbullying yang tercatat pada berbagai institusi di Yogyakarta jumlahnya relatif sedikit. Kasus cyberbullying yang ditangani oleh Polda DIY sebanyak empat kasus, kemudian Polresta Kota Yogyakarta menangani dua kasus, serta Yayasan Lembaga Perlindungan Anak DIY menangani enam remaja yang melakukan cyberbullying. Minimnya catatan kriminal pada institusi di Kota Yogyakarta terkait kasus cyberbullying tidak dapat semata-mata menjadi parameter dan menjustifikasi bahwa cyberbullying di Kota Yogyakarta rendah. Sebab sebagaimana telah kita ketahui, bahwa tidak semua kejahatan tercatat oleh kepolisian. Kriminalitas yang tercatat oleh polisi sebatas pada tindak pidana yang diketahui oleh pihak polisi saja. Banyak tindak pidana yang terjadi tetapi tidak diketahui oleh kepolisian, inilah yang disebut dark number (angka gelap kejahatan).

Menurut Pranawa, selaku Koordinator Layanan Hukum Yayasan Lembaga Perlindungan Anak DIY, menjelaskan bahwa kasus bullying baik yang dilakukan melalui media sosial maupun yang dilakukan secara tradisional sebenarnya sangat banyak di Kota Yogyakarta, akan tetapi hampir semuanya diselesaikan secara kekeluargaan dalam tataran sekolah. ${ }^{16}$ Sehingga dapat diketahui bahwa kejahatan yang tidak tercatat pihak kepolisan sejatinya jauh lebih banyak dari pada yang tercatat. Dalam konteks ini, banyaknya cyberbullying yang tidak tercatat oleh pihak kepolisian, sebagaimana yang dikatakan oleh Lidwina Esti Wulandari, selaku Ps. Panit 1 Subdit IV Direskrimum Polda DIY, disebabkan oleh beberapa faktor, antara lain:

a. Korban cyberbullying menganggap bahwa tidak begitu penting melaporkan kejadian itu pada polisi;

b. Kerumitan sistem pelaporan yang menghabiskan waktu dan bertele-tele;

c. Pelaku lihai menghilangkan jejak (pada kasus cyberbullying yang menggunakan akun yang tidak dikenali). ${ }^{17}$

\subsection{Usia Remaja Pelaku Cyberbullying di Kota Yogyakarta}

Membicarakan mengenai kenakalan remaja tentu penting untuk membahas rentang usia remaja yang melakukan kenakalan. Maka dari itu, penulis akan membagi remaja yang melakukan cyberbullying di Kota Yogyakarta berdasarkan tingkatan usianya. Adapun usia remaja yang melakukan cyberbullying, dan telah tercatat oleh institusi di Kota Yogyakarta sebagai berikut:

\footnotetext{
${ }^{16}$ Wawancara dengan Bapak Pranawa, S.H selaku Koorninator Layanan Hukum Yayasan Lembaga Perlindungan Anak DIY, pada tanggal 29 November 2019, Pukul 10.10 WIB.

${ }_{17}$ Wawancara dengan Ibu Lidwina Esti Wulandari, S.H selaku Ps. Panit 1 Subdit IV Direskrimum Polda DIY, pada tanggal 2 Desember 2019, Pukul 12.57 WIB.
} 
Tabel 2 Usia Pelaku Cyberbullying di Kota Yogyakarta

\begin{tabular}{|l||c|c|c|}
\hline No & Usia Pelaku & Frekuensi & Presentasi \\
\hline 1. & 13 tahun & 1 & $10 \%$ \\
\hline 2. & 14 tahun & 2 & $20 \%$ \\
\hline 3. & 15 tahun & - & - \\
\hline 4. & 16 tahun & 5 & $50 \%$ \\
\hline 5. & 17 tahun & 2 & $20 \%$ \\
\hline \hline
\end{tabular}

Sumber: Data Primer, diperoleh dari Polda DIY, Polresta Kota Yogyakarta, dan Yayasan Lembaga Perlindungan Anak DIY.

Usia remaja yang paling banyak melakukan cyberbullying sebagaimana data di atas adalah remaja berusia 16 tahun, terdapat lima pelaku atau sebesar 50\% yang tercatat melakukan cyberbullying. Selanjutnya sebanyak dua pelaku atau sebesar $20 \%$ adalah remaja berusia 14 tahun. Kemudian terdapat dua pelaku cyberbullying atau sebesar $20 \%$ merupakan remaja berusia 17 tahun. Sementara itu, terdapat satu atau sebesar $10 \%$ pelaku yang merupakan remaja berusia 13 tahun.

Pelaku kasus cyberbullying yang tercatat di Kota Yogyakarta paling banyak dilakukan oleh remaja berusia 16 tahun. Hal ini sesuai dengan berbagai teori yang menyatakan bahwa potensi kenakalan remaja (juvenile delinquency) paling banyak pada usia 16-17 tahun. Menurut sudut padang psikologi sebagaimana yang dijelaskan oleh Elizabeth B. Hurlock, usia 16-17 tahun disebut sebagai "krisis remaja". ${ }^{18}$ Pada usia ini remaja akan mengalami gejolak pencarian jati diri. Pada fase tersebut seorang remaja rentan melakukan kenakalan berupa pelanggaran norma-norma hukum, sosial, susila, dan agama.

\subsection{Tingkat Pendidikan Pelaku Cyberbullying di Kota Yogyakarta}

Suatu bentuk kenakalan remaja tertentu terkadang dipengaruhi oleh jenjang pendidikan seseorang. Maka dari itu penulis mencoba memaparkan pelaku cyberbullying berdasarkan jenjang pendidikannya. Hasilnya sebagaimana tabel di bawah ini:

${ }^{18}$ Elizabeth B. Hurlock, dalam Sudarsono. (2015). Kenakalan Remaja: Prevensi, Rehabilitasi, dan Resosialisasi. Jakarta: Rineka Cipta, hlm.14. 
Tabel 3 Tingkat Pendidikan Pelaku Cyberbullying di Kota Yogyakarta

\begin{tabular}{|l|c|c|c|}
\hline No & Pendidikan & Frekuensi & Presentasi \\
\hline 1. & Sekolah Menengah Pertama (SMP) & 3 & $30 \%$ \\
\hline 2. & SMA/SMK/ Sederajat & 7 & $70 \%$ \\
\hline \multicolumn{2}{|c|}{ Jumlah } & 10 & $100 \%$ \\
\hline
\end{tabular}

Sumber: Data Primer, diperoleh dari Polda DIY, Polresta Kota Yogyakarta, dan Yayasan Lembaga Perlindungan Anak DIY.

Sesuai dengan data yang tercatat oleh institusi di kota Yogyakarta, pelaku cyberbullying berdasarkan tingkat pendidikannya, maka di ketahui bahwa pelaku cyberbullying di Kota Yogyakarta seluruhnya adalah pelajar. Di mana rinciannya sebanyak tujuh orang atau 70\% adalah pelajar pada tingkat SMA/SMK/Sederajat. Sementara itu sisanya sebanyak dua orang atau 30\% adalah pelajar Sekolah Menengah Pertama (SMP). Dari data tersebut terlihat jelas bahwa pelaku cyberbullying adalah remaja-remaja terdidik. Pelaku cyberbullying didominasi oleh pelajar, sebab korban dari perbuatan tersebut umumnya adalah teman satu sekolah yang memang sudah sering berinteraksi baik di dunia nyata maupun melalui jaringan internet.

\subsection{Jenis Kelamin Pelaku Cyberbullying di Kota Yogyakarta}

Berbagai teori mengenai kenakalan remaja mengaitkan tipe kenakalan tertentu dengan jenis kelamin. Maka sesuai dengan hasil penelitian, penulis akan memaparkan pelaku cyberbullying yang tercatat pada berbagai institusi di Kota Yogyakarta berdasarkan jenis kelamin sebagai berikut:

Tabel 4 Pelaku Cyberbullying yang Berdasarkan Jenis Kelamin

\begin{tabular}{|c|c|c|c|}
\hline No & Pelaku & Frekuensi & Presentasi \\
\hline 1. & Laki-laki & 10 & $100 \%$ \\
\hline 2. & Perempuan & - & - \\
\hline \multicolumn{2}{|r|}{ Jumlah } & 10 & $100 \%$ \\
\hline
\end{tabular}

Sumber: Data Primer, diperoleh dari Polda DIY, Polresta Kota Yogyakarta, dan Yayasan Lembaga Perlindungan Anak DIY.

Sesuai dengan data yang tercatat oleh institusi di kota Yogyakarta, pelaku cyberbullying berdasarkan jenis kelamin, 100 \% pelakunya adalah laki-laki. Sebanyak sepuluh dari total sepuluh pelaku berjenis kelamin laki-laki. Ini berbeda dengan penelitian yang dilakukan oleh banyak peneliti dari luar negeri, yang menunjukan bahwa perempuan lebih dominan melakukan cyberbullying karena sifat tidak langsung 
dari kejahatan tersebut. Sementara itu, laki-laki lebih cenderung melakukan kenakalan dengan menggunakan kekuatan fisik. ${ }^{19}$

Penelitian yang dilakukan oleh Sameer Hinduja dan Justin W. Patchin dari Cyberbullying Research Center pada tahun 2009 di Amerika Serikat, mengungkapkan bahwa cyberbullying didominasi oleh perempuan. ${ }^{20}$ Perbedaan mencolok dari penelitian yang dilakukan di Amerika Serikat dengan fakta yang ditemukan oleh penulis di Kota Yogyakarta, dilandasi oleh berbagai faktor. Sebagaimana yang dijelaskan oleh Nur Fauzan, selaku Ps. Kasubnit IV Reskrim Polresta Yogyakarta, ada beberapa faktor yang menyebabkan pelaku cyberbullying di Kota Yogyakarta didominasi oleh laki-laki, yaitu:

a. Pelaku cyberbullying menggunakan akun yang dikenali;

b. Pelaku dan korban cyberbullying sudah saling kenal;

c. Cyberbullying merupakan pemicu tindak pidana kekerasan fisik;

d. Cyberbullying dan bullying secara tradisional dilakukan secara bersamasama. ${ }^{21}$

Berdasarkan faktor-faktor di atas wajar kiranya apabila pelaku cyberbullying di Kota Yogyakarta didominasi oleh laki-laki. Sebab meskipun cyberbullying dilakukan dengan tidak bertatap muka secara langsung, namun kedua belah pihak sudah saling mengenal, sehingga pelaku sudah mempertimbangkan bahwa dia adalah pihak yang dominan secara kekuatan fisik. Selain itu, pelaku cyberbullying telah mempersiapkan diri jika ada potensi terjadi kontak fisik. Ini berbeda dengan cyberbullying yang banyak dilakukan oleh remaja di Amerika Serikat, di mana pelaku cenderung secara sengaja dan terencana melakukan cyberbullying untuk menekan habis-habisan pihak korban dengan menggunakan akun anonim (tidak dikenali). Pelaku menggunakan akun yang tidak dikenali sebab, dia tidak ingin atau tidak memiliki keberanian untuk melakukan kontak fisik, sehingga wajar jika cyberbullying di Amerika Serikat justru didominasi oleh perempuan.

\subsection{Korban Cyberbullying di Kota Yogyakarta}

Korban kejahatan merupakan objek penelitian kriminologi yang tidak dapat dilepaskan dari gejala kejahatan. Dapat dipastikan bahwa setiap kejahatan ada korbannya, baik orang lain maupun diri sendiri. Banyak orang beranggapan bahwa

\footnotetext{
${ }^{19}$ Catherine D. Marcum, George E. Higgins. (2019). Examining the Effectiveness of Academic Scholarship on the Fight Against Cyberbullying and Cyberstalking. American Journal of Criminal Justice, Vol.11, No.2, hlm. 647.

${ }^{20}$ Sameer Hinduja, Justin W. Patchin. (2008). Cyberbullying: An Exploratory Analysis of Factors Related to Offending And Victimization. Deviant Behavior, Vol.11, No.3, hlm. 131.

${ }^{21}$ Wawancara dengan Bapak Nur Fauzan, S.H selaku Ps. Kasubnit IV Reskrim Polresta Yogyakarta, pada tanggal 4 Desember, Pukul 10.43 WIB.
} 
korban kejahatan hanya sekadar pelengkap penderita bagi timbulnya suatu peristiwa kejahatan. Padahal pemikiran tersebut keliru, sebab korban sejatinya memiliki peranan yang besar bagi timbulnya suatu kejahatan. Oleh karena pentingnya peranan korban dalam memahami suatu kejahatan, maka dari itu penulis akan menjelaskan korban dari cyberbullying yang tercatat pada berbagai institusi di Kota Yogyakarta, antara lain sebagai berikut:

Tabel 5 Korban Cyberbullying di Kota Yogyakarta

\begin{tabular}{|c|c|c|c|}
\hline No & Korban & Frekuensi & Presentasi \\
\hline 1. & $\begin{array}{c}\text { Remaja Laki-laki } \\
(12-17 \text { tahun })\end{array}$ & 2 & $33,3 \%$ \\
\hline 2. & $\begin{array}{c}\text { Remaja Perempuan } \\
(12-17 \text { tahun })\end{array}$ & 2 & $33,3 \%$ \\
\hline 3. & Institusi & 2 & $33,3 \%$ \\
\hline \hline & Jumlah & 6 & $100 \%$ \\
\hline
\end{tabular}

Sumber: Data Primer, diperoleh dari Polda DIY, Polresta Kota Yogyakarta, dan Yayasan Lembaga Perlindungan Anak DIY.

Korban dari cyberbullying di Kota Yogyakarta sebagian besar adalah remaja lakilaki dan remaja perempuan, keduanya sama-sama terdapat dua korban. Hal ini terjadi karena perilaku cyberbullying di Kota Yogyakarta kebanyakan terjadi dalam ruang lingkup sekolah. Sebagaian besar pelaku maupun korban merupakan teman sebaya yang telah saling mengenal satu sama lain. Hal tersebut yang menjadi alasan sangat jarang cyberbullying yang dilakukan oleh remaja ditujukan kepada anak-anak dan orang dewasa. Selain itu, berbeda dengan pelaku yang seluruhnya adalah remaja lakilaki, pada pihak korban terdapat remaja perempuan.

Selain person (manusia), korban cyberbullying lainnya adalah institusi. Dalam hal ini institusi yang diserang adalah Kepolisian. Pranawa selaku Koorninator Layanan Hukum Yayasan Lembaga Perlindungan Anak DIY mengungkapkan bahwa kasus cyberbullying, di mana Institusi Kepolisian yang menjadi korbannya, terjadi karena adanya interaksi di dunia nyata antara pelaku dengan salah seorang yang bekerja di institusi tersebut. Namun si pelaku tidak berdaya dan tidak memiliki kekuatan untuk berhadapan dengan polisi tersebut, maka pelaku melampiaskannya melalui aksi cyberbullying. ${ }^{22}$

${ }^{22}$ Wawancara dengan Bapak Pranawa, S.H selaku Koorninator Layanan Hukum Yayasan Lembaga Perlindungan Anak DIY, pada tanggal 29 November 2019, Pukul 10.10 WIB. 


\subsection{Media yang Digunakan Pelaku Cyberbullying}

Agar dapat dikatakan suatu perbuatan sebagai aksi cyberbullying, maka perbuatan tersebut harus dilakukan melalui media dalam jaringan internet. Adapun sesuai dengan penelitian yang penulis dapatkan dari kasus cyberbullying yang tercatat pada institusi di Kota Yogyakarta, media yang digunakan oleh pelaku cyberbullying antara lain sebagai berikut:

Tabel 6. Media yang Digunakan Pelaku Untuk melakukan Cyberbullying

\begin{tabular}{|l|c|c|c|}
\hline No & Media & Frekuensi & Presentasi \\
\hline 1. & WhatsApp & 4 & $40 \%$ \\
\hline 2. & Facebook & 3 & $30 \%$ \\
\hline 3. & Instagram & 3 & $30 \%$ \\
\hline \hline \multicolumn{2}{|l|}{ Jumlah } & 10 & $100 \%$ \\
\hline
\end{tabular}

Sumber: Data primer, diperoleh dari Polda DIY, Polresta Kota Yogyakarta, dan Yayasan Lembaga Perlindungan Anak DIY.

Media yang paling sering digunakan untuk melancarkan aksi cyberbullying, sebagaimana data di atas adalah WhatsApps dengan total empat kasus atau dengan presentase $40 \%$. Empat kasus cyberbullying tersebut dilakukan pada chat rooms grup WhatsApp. Selanjutnya terdapat tiga kasus atau dengan presentasi 30\% menggunakan Instagram sebagai media untuk melakukan aksi cyberbullying. Kemudian terdapat tiga kasus atau dengan presentasi sebesar 30\% cyberbullying yang menggunakan media sosial facebook. Sebenarnya frekuensi penggunaan media untuk melakukanan cyberbullying bergantung pada tren pemakaian media sosial. Kasus cyberbullying yang dilakukan dengan menggunakan media facebook terjadi pada tahun 2017, di mana media sosial facebook pada masa itu masih cukup populer. Sementara itu kasus cyberbullying yang menggunakan media sosial WhatsApp dan Instagram didominasi oleh kasus yang terjadi di tahun 2019, di mana pada tahun 2019 penggunaan dua media tersebut adalah yang paling masif di Indonesia.

\subsection{Data Responden}

Penulis juga melakukan penelitaian ke Sekolah Menengah Atas (SMA) 7 Kota Yogyakarta, untuk menyebar 50 kuesioner yang ditujukan kepada siswa-siswi berusia 15 tahun sampai dengan 17 tahun. Terdapat 13 pertanyaan yang harus dijawab oleh responden dengan format sebagai berikut: S: Setuju, SS: Sangat Setuju, TS: Tidak Setuju, STS: Sangat tidak setuju. Di mana disetiap pertanyaan responden diwajibkan untuk memilih salah satu (multiple choice questions). Adapun hasil kuesioner tersebut sebagaimana tabel di bawah ini: 
Tabel 7 Data Kuesioner Responden

\begin{tabular}{|c|c|c|c|c|c|}
\hline No & Daftar Pertanyaan & S & SS & TS & STS \\
\hline 1. & $\begin{array}{l}\text { Saya sangat sering menggunakan media sosial } \\
\text { (WhatsApp, Instagram, Twitter, dll) }\end{array}$ & 24 & 24 & 2 & 0 \\
\hline 2. & Saya sering melakukan cyberbullying & 11 & 0 & 26 & 13 \\
\hline 3. & Saya sering menjadi korban cyberbullying & 9 & 0 & 21 & 20 \\
\hline 4. & $\begin{array}{l}\text { cyberbullying merupakan perilaku yang dikecam } \\
\text { oleh masyarakat }\end{array}$ & 21 & 29 & 0 & 0 \\
\hline 5. & $\begin{array}{l}\text { Pelaku cyberbullying melancarkan aksinya } \\
\text { dengan menggunakan akun yang dikenali }\end{array}$ & 17 & 4 & 22 & 7 \\
\hline 6. & $\begin{array}{l}\text { Seseorang melakukan cyberbullying karena } \\
\text { perkembangan teknologi yang semakin pesat }\end{array}$ & 29 & 21 & 0 & 0 \\
\hline 7. & $\begin{array}{l}\text { Seseorang melakukan cyberbullying karena } \\
\text { meniru orang lain di media social }\end{array}$ & 19 & 31 & 0 & 0 \\
\hline 8. & $\begin{array}{l}\text { Seseorang melakukan cyberbullying karena ikut- } \\
\text { ikutan teman }\end{array}$ & 24 & 20 & 6 & 0 \\
\hline 9. & $\begin{array}{l}\text { Seseorang melakukan cyberbullying karena } \\
\text { melihat tanyangan kekerasan dan cibiran di } \\
\text { televisi }\end{array}$ & 31 & 10 & 9 & 0 \\
\hline 10. & $\begin{array}{l}\text { Seseorang melakukan cyberbullying karena } \\
\text { kurangnya kelekatan dengan keluarga }\end{array}$ & 24 & 11 & 15 & 0 \\
\hline 11. & $\begin{array}{l}\text { Seseorang melakukan cyberbullying karena ingin } \\
\text { mencari perhatian }\end{array}$ & 33 & 8 & 8 & 1 \\
\hline 12. & $\begin{array}{l}\text { Seseorang melakukan cyberbullying karena tidak } \\
\text { tahu bahwa perbuatan tersebut melanggar } \\
\text { hukum }\end{array}$ & 27 & 5 & 16 & 2 \\
\hline 13. & $\begin{array}{l}\text { Upaya yang dilakukan oleh aparat penegak } \\
\text { hukum dalam memberantas cyberbullying sudah } \\
\text { efektif }\end{array}$ & 5 & 5 & 38 & 2 \\
\hline \multicolumn{2}{|r|}{ JUMLAH } & 274 & 168 & 163 & 45 \\
\hline
\end{tabular}

Sumber: Data primer, Hasil data Kuesioner dari responden pelajar berusia 15 tahun sampai dengan 17 tahun di SMA 7 Yogyakarta. 
Berdasarkan tabel 9 sebagaimana di atas, dapat diketahui bahwa dari 50 responden yang mengisi kuesioner terdapat masing-masing 24 orang yang menyatakan setuju dan sangat setuju bahwa mereka sangat sering menggunakan media sosial (WhatsApp, Instagram, Twitter, dll). sementara hanya terdapat 2 responden yang menyatakan tidak setuju. Selanjutnya terdapat 11 responden yang setuju bahwa mereka sering melakukan cyberbullying. Sementara itu, terdapat 26 responden yang menyatakan tidak setuju dan 13 responden menyatakan sangat tidak setuju. Pertanyaan selanjutnya adalah berkaitan dengan seberapa sering mereka menjadi korban cyberbullying. Sebanyak 9 responden setuju bahwa mereka sering menjadi korban cyberbullying. Sementara itu, sebanyak 21 responden menyatakan tidak setuju dan 21 responsen menyebutkan sangat tidak setuju. Pertanyaan berikutnya yaitu cyberbullying sebagai perilaku yang dikecam oleh masyarakat. Di mana sebanyak 21 responden menyatakan setuju dan 29 lainnya menyatakan sangat setuju.

Pertanyaan yang diajukan selanjutnya adalah identitas pelaku saat melakukan cyberbullying. Sebanyak 17 responden menyetujui bahwa identitas pelaku dikenali. Sementara itu terdapat sebanyak 4 responden sangat setuju, 22 responden tidak setuju dan 7 responden menyatakan sangat tidak setuju. Pertanyaan selanjutnya berkaitan dengan faktor-faktor yang menyebabkan seseorang melakukan perbuatan cyberbullying. Di mana secara umum responden menyetujui bahwa faktor-faktor yang menyebabkan seseorang melakukan cyberbullying adalah: pesatnya perkembangan teknologi, sifat anak yang suka meniru, ketidaklekatan hubungan dengan keluarga, serta ketidaktahuan dengan risiko hukum. Selain itu penulis juga memberikan pertanyaan terkait dengan efektifitas penegakan hukum terhadap pelaku cyberbullying. Mayorits responden tidak setuju, yang artinya responden menganggap bahwa penegakan hukum terhadap pelaku cyberbullying oleh penegak hukum tidak teraplikasikan secara efektif.

\subsection{Faktor-Faktor Penyebab Cyberbullying yang Dilakukan Oleh Remaja di Kota} Yogyakarta

Mempelajari serta menemukan faktor-faktor yang menyebabkan seseorang melakukan kejahatan memiliki perananan yang penting guna menentukan kebijakan kriminal (criminal policy) yang tepat dalam rangka memberantas kejahatan. Maka dari itu penulis akan memaparkan faktor-faktor yang menyebabkan remaja melakukan cyberbullying di Kota Yogyakarta. Setelah penulis melakukan penelitian, ditemukan faktor-faktor yang menyebabkan remaja melakukan cyberbullying di Kota Yogyakarta antara lain sebagai berikut: 


\subsubsection{Pesatnya Perkembangan Teknologi}

Pesatnya laju modernisasi telah membawa perubahan secara signifikan dalam hal teknologi. Dampak dari perubahan teknologi informasi dan komunikasi pun pada akhirnya turut mengubah pola kehidupan dan lingkungan belajar serta bermain remaja di Kota Yogyakarta. Hadirnya jaringan internet, termasuk di dalamnya adalah media sosial, games online, situs web pribadi, ruang obrolan, email, dan pesan teks atau gambar digital, telah menjadi sarana yang mampu membuat banyak orang berinteraksi dalam dunia maya. Ketika terdapat interaksi dari banyak manusia, maka konflik tidak dapat dihindari. Berbagai masalah akan timbul sebagai konsekuensi langsung dari cepatnya perkembangan teknologi. Jaringan internet dewasa ini telah menjadi fasilitas bagi aksi cyberbullying di Kota Yogyakarta.

Banyak remaja di Kota Yogyakarta telah mengalami pergeseran pola bermain, yang dulunya dilakukan dengan berinteraksi di luar rumah, kini sedikit demi sedikit digantikan oleh interaksi di dunia maya, seperti media sosial dan games online. Penggunaan jaringan internet dengan intensitas yang tinggi ini yang membuat seorang remaja rentan melakukan cyberbullying. Salah satu contohnya, Sebagaimana yang dijelaskan oleh Wine Safitri selaku Kasubsi Bimbingan Kemasyarakatan Anak, berdasarkan hasil penelitian kemasyarakatan, pada kasus anak dengan inisial MB yang merupakan pelaku cyberbullying, ternyata diketahui sudah tiga tahun sering pergi ke warnet untuk bermain game online sebelum akhirnya, ia melakukan aksi cyberbullying. MB biasanya bermain di warnet hingga larut malam, bahkan terkadang ia tidak pulang ke rumah dan tidur di warnet. ${ }^{23}$

Sebanyak empat dari empat responden pelaku bullying tradisional dan cyberbullying yang sedang mendapatkan rehabilitasi di Balai Perlindungan dan Rehabilitasi Sosial Remaja Yogyakarta menjelaskan bahwa mereka kecanduan berselancar di dunia maya, terutama bermain games online dan media sosial.24 Berdasarkan berbagai contoh di atas, dapat diketahui bahwa semakin tinggi intensitas interaksi seseorang di dunia maya, maka semakin besar peluang ia melakukan cyberbullying.

Cyberbullying memiliki perbedaan dengan bullying yang dilakukan secara tradisional. Apabila bullying tradisional mensyaratkan pelaku dan korban berinteraksi secara langsung, namun tidak demikian dengan aksi cyberbullying. Sifat tidak langsung dari cyberbullying ini yang menjadi alasan maraknya aksi cyberbullying di Kota Yogyakarta. Sebab pelaku tidak terlihat secara langsung, serta dapat berlindung dibalik ponsel atau komputer.

${ }^{23}$ Wawancara dengan Ibu Wine Safitri selaku Kasubsi Bimbingan Kemasyarakatan Anak, pada tanggal 10 Desember, Pukul 10.04 WIB.

${ }^{24}$ Wawancara dengan Responden remaja yang sedang mendapatkan rehabilitasi di Balai Perlindungan dan Rehabilitasi Sosial Remaja Yogyakarta. 
Hal ini diperkuat dengan pengakuan dua responden remaja di Balai Perlindungan dan Rehabilitasi Sosial Remaja Yogyakarta. Mereka menyatakan bahwa motivasinya melakukan bullying tradisional dan cyberbullying itu berbeda. Ia melakukan bullying tradisional karena memang pihak korban adalah pihak yang lebih lemah baik secara kedudukan maupun fisiknya. Sehingga ia dapat melakukan bullying berupa intimidasi dan kekerasan tanpa takut mendapatkan balasan. Sementara itu, motivasinya melakukan cyberbullying adalah karena ia dapat mengintimidasi dan mempermalukan korban dengan dampak yang sama tanpa harus menimbangnimbang kekuatan fisik karena sifat tidak langsung dari cyberbullying. ${ }^{25}$

\subsubsection{Ketidaktahuan Akan Risiko Hukum}

Setelah penulis melakukan penelitian di berbagai tempat, ditemukan faktor berikutnya yang menyebabkan remaja melakukan cyberbullying di Kota Yogyakarta. Pranawa selaku Koordinator Devisi Layanan Hukum Yayasan Lembaga Perlindungan Anak DIY, Nur Fauzan selaku Ps. Kasubnid IV Direskrim Polresta Yogyakarta, dan Lidwina Esti Wulandari selaku Ps. Panit 1 Subdit IV Direskrimum Polda DIY, semuanya sepakat bahwa ketidaktahuan akan risiko hukum yang menyebabkan maraknya cyberbullying di Kota Yogyakarta. Pelaku cyberbullying kebanyakan tidak mengetahui bahwa perbuatan yang mereka lakukan adalah pelanggaran hukum. Mereka tidak mengetahui bahwa dari perbuatan tersebut, mereka dapat dikenai sanksi pidana. Para pelaku cyberbullying tersebut menganggap bahwa apa yang mereka lakukan hanya sebatas ungkapan ekspresi diri, atau bahkan beberapa di antaranya berdalih bahwa yang mereka lakukan hanyalah gurauan semata.

Berdasarkan keterangan Lidwina Esti Wulandari selaku Ps. Panit 1 Subdit IV Direskrimum Polda DIY menyebutkan bahwa remaja berinisial SR dan SCE yang merupakan pelaku cyberbullying, mereka tidak mengerti, tidak mengetahui, bahkan tidak menyangka bahwa hanya karena menggolok-olok temannya di grup WhatsApp ternyata dapat berbuntut panjang hingga harus diselesaikan di kepolisian. ${ }^{26}$ Kemudian Pranawa selaku Koordinator Divisi Layanan Hukum Yayasan Lembaga Perlindungan Aanak DIY, menyatakan bahwa lima dari enam pelaku kasus cyberbullying yang didampingi oleh Yayasan Lembaga Perlindungan Aanak DIY ternyata tidak memahami bahwa perbuatan mereka memiliki risiko hukumnya. Hal ini disebabkan karena undang-undang informasi dan transaksi elektronik itu baru dan belum banyak masyarakat yang memahaminya. ${ }^{27}$

\footnotetext{
${ }^{25}$ Wawancara dengan Responden remaja yang sedang mendapatkan rehabilitasi di Balai Perlindungan dan Rehabilitasi Sosial Remaja Yogyakarta.

${ }^{26}$ Wawancara dengan Ibu Lidwina Esti Wulandari selaku Ps. Panit 1 Subdit IV Direskrimum Polda DIY, pada tanggal 2 Desember 2019, Pukul 12.57 WIB.

${ }^{27}$ Wawancara dengan Bapak Pranawa, S.H selaku Koorninator Layanan Hukum Yayasan Lembaga Perlindungan Anak DIY, pada tanggal 29 November 2019, Pukul 10.10 WIB.
} 
Ketidaktahuan akan risiko hukum juga dapat dilihat dari remaja pelaku cyberbullying yang umumnya menggunakan akun yang dikenali. Ini berbeda dengan cyberbullying yang dilakukan oleh orang dewasa, di mana sebanyak enam dari sembilan kasus cyberbullying yang dilakukan oleh orang dewasa yang ditangani oleh Reserse Kriminal Khusus Polda DIY pada tahun 2019 menggunakan akun yang tidak dikenali (anonymity). ${ }^{28}$ Sebab mereka paham betul bahwa dengan menggunakan akun anonymity, mereka akan lebih terlindungi, karena hal tersebut akan menyulitkan pihak kepolisian dalam mengungkap aksi cyberbullying. Sementara remaja dengan berani menunjukkan identitasnya saat melakukan aksi cyberbullying disebabkan sifat remaja yang terlalu polos dan tidak menyadari bahwa dengan menggunakan akun yang dikenali akan memudahkan pihak kepolisian untuk melacak keberadaannya.

\subsubsection{Perilaku Remaja yang Suka Meniru}

Remaja merupakan masa transisi dari anak-anak menuju dewasa. Pada masa ini remaja memiliki kecenderungan labil, tengah mencari jati diri, dan antusias dalam mengeksplorasi banyak hal. Pada tahap ini remaja memiliki kecenderungan untuk melihat dan mempelajari berbagai hal dari lingkungan sekitarnya. Pembelajaran remaja selalui diidentikkan sebagai berbagai interaksi dengan kelompok-kelompok yang memiliki kelekatan hubungan dengan dirinya, seperti keluarga, saudara, dan teman sebaya. Sebagai contoh adalah kasus cyberbullying yang dilakukan oleh remaja berinisial JTAF yang mengolok-olok institusi kepolisian, kemudian tingkah laku tersebut ditiru dan didukung oleh teman dekatnya berinisial DNC, dan DPA. ${ }^{29}$

Di era modern ini, remaja tidak hanya dapat mempelajari tingkah laku dengan orang-orang terdekat saja. Hadirnya media sosial menciptakan interaksi yang lekat tanpa harus saling kenal satu sama lain. Masalahnya banyak perilaku negatif yang dilakukan oleh banyak orang di media sosial yang pada akhirnya ditiru oleh remaja. Ini yang dialami oleh remaja berinisial SR dan SCE, mereka secara berulang-ulang melakukan cyberbullying dengan menyebarkan foto korban yang telah diedit sedemikian rupa yang berbau pelecehan. sebagaimana keterangan yang disampaikan oleh Lidwina Esti Wulandari selaku Ps. Panit 1 Subdit IV Direskrimum Polda DIY, bahwa kedua remaja yang melakukan cyberbullying tersebut mengaku mempelajari tingkah lagu cyberbullying dari orang lain di media sosial. Mereka melihat tren penggunaan "meme" di media sosial dan kemudian diikutinya. ${ }^{30}$

\footnotetext{
${ }^{28}$ Data Kasus Cyberbullying yang di peroleh dari Polda DIY, pada tanggal 18 Desember 2019, Pukul 13.30 WIB.

${ }^{29}$ Wawancara dengan Bapak Pranawa, S.H selaku Koorninator Layanan Hukum Yayasan Lembaga Perlindungan Anak DIY, pada tanggal 29 November 2019, Pukul 10.10 WIB.

${ }^{30}$ Wawancara dengan Ibu Lidwina Esti Wulandari selaku Ps. Panit 1 Subdit IV Direskrimum Polda DIY, pada tanggal 2 Desember 2019, Pukul 12.57 WIB.
} 
Perilaku remaja yang suka meniru juga dapat dilihat dari bullying secara tradisional yang dilakukan oleh beberapa remaja yang sedang mendapatkan rehabilitasi di Balai Perlindungan dan Rehabilitasi Sosial Remaja Yogyakarta. Awal mulanya satu remaja senior yang di sana melakukan intimidasi dan kekerasan fisik kepada remaja junior. Kemudian tindakan bullying tersebut ditiru dan dilakukan oleh dua remaja lainnya. Ketika diwawancarai oleh penulis, dua responden tersebut mengungkapkan bahwa sebenarnya sebelumnya mereka tidak pernah melakukan bullying. Pembelajaran melakukan bullying terjadi di Balai Perlindungan dan Rehabilitasi Sosial Remaja Yogyakarta, di mana perilaku tersebut dilakukan dengan meniru remaja yang lebih senior melakukan bullying. ${ }^{31}$

Aksi cyberbullying terjadi karena prilaku remaja yang suka meniru tingkah laku disekitarnya ini sesuai dengan diferential association theory dari Edwin H. Sutherland yang menjelaskan bahwa "criminal behavior is learned in interaction with other person in process of communication" 32 (tingkah laku kriminal dipelajari dalam interaksi dengan orang lain dalam suatu komunikasi). Seseorang anak tidak begitu saja menjadi delinquent hanya karena hidup dalam suatu lingkungan kriminal, namun sifat delinquent tersebut dipelajari dengan partisipasi bersama orang lain baik dalam komunikasi secara verbal maupun non-verbal.

\subsubsection{Melemahnya Kontrol Sosial}

Setelah penulis melakukan penelitian di berbagai tempat di Yogyakarta, ditemukan fakta bahwa cyberbullying yang terjadi di Kota Yogyakarta dapat dilakukan oleh siapapun. Meskipun ditemukan kecenderungan pada ciri tertentu, namun secara general kenakalan ini tidak memandang faktor ekonomi, maupun faktor pendidikan. Pelaku cyberbullying dapat dilakukan oleh remaja dengan tingkat ekonomi rendah ataupun remaja yang lahir dari keluarga yang berkecukupan. Ditemukan pelaku cyberbullying yang merupakan remaja gemar bolos sekolah, namun juga terdapat remaja yang memiliki riwayat akademik yang baik.

Faktor yang menyebabkan seseorang melakukan cyberbullying selanjutnya terjadi karena melemah atau bahkan hilangnya kontrol sosial. Kontrol sosial dalam hal ini terbagai menjadi personal kontrol dan sosial kontrol. Pertama, kontrol internal atau personal control yaitu kemampuan seseorang untuk menahan diri agar tidak mencapai kebutuhannya dengan melanggar norma-norma yang ada di masyarakat. Sebagai contoh, seorang remaja berinisial MB melakukan cyberbullying didasarkan karena rasa kesal terhadap korban. Sifat temperamen yang tinggi dan ketidakmampuan untuk

\footnotetext{
${ }^{31}$ Wawancara dengan Responden remaja yang sedang mendapatkan rehabilitasi di Balai Perlindungan dan Rehabilitasi Sosial Remaja Yogyakarta.

${ }^{32}$ Edwin H. Sutherland, dalam Paulus Hadisuprapto. (2006). Juvenile Delinquency: Pemahaman dan Penangunangannya. Bandung: PT. Citra Aditya Bakti, hlm. 20.
} 
menahan diri ini lah yang memicu pelaku melakukan cyberbullying. Berdasarkan hasil penelitian Balai Pemasyarakatan Kelas I Yogyakarta, ditemukan fakta bahwa melemahnya personal control dari MB disebabkan oleh semakin menjauhnya MB dari nilai-nilai agama. ${ }^{33}$

Melemahnya personal control juga terjadi pada kasus yang dialami oleh empat responden remaja di Balai Perlindungan dan Rehabilitasi Sosial Remaja Yogyakarta, Mereka mengaku mendapatkan kepuasan diri dalam melakukan bullying tradisional dan cyberbullying. Meskipun mereka mengetahui bahwa perbuatannya adalah sesuatu yang tidak baik dan dapat merugikan orang lain, namun mereka tetap melakukan cyberbullying karena ketidakmampuan mereka untuk menahan diri. ${ }^{34}$

Melemahnya kontrol sosial juga dapat melibatkan faktor eksternal atau social control, yaitu kemampuan kelompok sosial atau lembaga-lembaga di masyarakat melaksanakan norma-norma atau peraturan-peraturan menjadi efektif. Cyberbullying terjadi karena melemahnya kontrol sosial dari keluarga, teman, dan masyarakat. Nilainilai dan etika dalam bertutur kata dan bertindak lambat laun semakin memudar yang disebabkan oleh laju modernisasi. Menurut pandangan penulis, lembaga kontrol sosial tidak lagi mampu untuk membimbing masyarakatnya, dalam hal ini remaja untuk memiliki etika dalam berinteraksi dengan orang lain. Selain itu banyak kasus baik bullying tradisional maupun cyberbullying terjadi karena melemahnya peran norma agama dan norma sosial dalam diri si remaja. Dalam hal ini masyarakat dan keluarga tidak mampu membimbing remaja tersebut. Sebagai contoh pada kasus remaja berinisial $\mathrm{MB}$, di mana orang tua pelaku membiarkan pelaku bermain game di warnet hingga tengah malam, bahkan terkadang tidak pulang ke rumah. ${ }^{35}$

Melemahnya social control juga dapat terlihat dari kasus yang dialami oleh empat responden remaja di Balai Perlindungan dan Rehabilitasi Sosial Remaja Yogyakarta, Mereka mengaku telah jauh dari nilai-nilai agama. Selain itu mereka juga mengaku selama ini tidak mendapatkan pengawasan yang baik dari orang tua maupun lingkungan sekitar tempat tinggalnya. ${ }^{36}$

\section{Kesimpulan}

Jaringan internet berupa media sosial, game online, dan media komunikasi digital lainnya, dewasa ini telah menjadi fasilitas bagi terjadinya cyberbullying yang dilakukan

\footnotetext{
${ }^{33}$ Data hasil penelitian kemasyarakatan yang dilakukan oleh Balai Kemasyarakatan Kelas I Yogyakarta.

${ }^{34}$ Wawancara dengan Responden remaja yang sedang mendapatkan rehabilitasi di Balai Perlindungan dan Rehabilitasi Sosial Remaja Yogyakarta.

${ }^{35}$ Data hasil penelitian kemasyarakatan yang dilakukan oleh Balai Kemasyarakatan Kelas I Yogyakarta.

${ }^{36}$ Wawancara dengan Responden remaja yang sedang mendapatkan rehabilitasi di Balai Perlindungan dan Rehabilitasi Sosial Remaja Yogyakarta.
} 
oleh remaja di Kota Yogyakarta. Kasus cyberbullying yang dilakukan oleh remaja terus meningkat setiap tahunnya. Maka penting kiranya untuk mengetahui faktor penyebab remaja melakukan cyberbullying. Sehingga diharapkan dengan mengetahui faktor penyebab yang memengaruhi remaja melakukan cyberbullying, kita dapat mengetahui kebijakan kriminal (criminal policy) yang tepat guna memberantas cyberbullying secara lebih efektif. ada pun berdasarkan hasil hasil penelitian, penyebab remaja melakukan cyberbullying di Kota Yogyakarta sebagai berikut:

a. Pesatnya perkembangan teknologi: pesatnya laju modernisasi telah membawa perubahan pola bermain. Penggunaan jaringan internet dengan intensitas yang tinggi yang membuat seorang remaja rentan melakukan cyberbullying. Selain itu, sifat tidak langsung dari cyberbullying juga memengaruhi seseorang melakukan cyberbullying;

b. Ketidaktahuan akan risiko hukum: pelaku cyberbullying kebanyakan tidak mengetahui bahwa perbuatan yang mereka lakukan adalah pelanggaran hukum. Mereka tidak mengetahui bahwa dari perbuatan tersebut mereka dapat dikenai sanksi pidana;

c. Perilaku remaja yang suka meniru: remaja merupakan masa transisi dari anakanak menuju dewasa. Pada tahap ini remaja memiliki kecenderungan untuk melihat dan mempelajari berbagai hal dari lingkungan sekitarnya. Pembelajaran tersebut dilakukan dengan kelompok-kelompok yang memiliki kelekatan hubungan dengan dirinya, seperti keluarga, saudara, dan teman sebaya;

d. Melemahnya kontrol sosial: cyberbullying yang terjadi di Kota Yogyakarta disebabkan oleh melemahnya kontrol sosial. Kontrol sosial terbagai menjadi: personal control yaitu kemampuan seseorang untuk menahan diri agar tidak mencapai kebutuhannya dengan melanggar norma-norma yang ada di masyarakat. kedua, social control, yaitu kemampuan kelompok sosial atau lembaga-lembaga di masyarakat melaksanakan norma-norma atau peraturanperaturan menjadi efektif.

\section{Daftar Pustaka}

\section{Buku}

Dey Ravena, Kristian. (2017). Kebijakan Kriminal (Criminal Policy). Jakarta: Kencana.

Maskun. (2014). Kejahatan Siber (Cyber Crime): Suatu Pengantar. Jakarta: Prenada Media Group.

Muhammad Mustofa. (2015). Metodologi Penelitian Kriminologi. Jakarta: Kencana.

Mukti Fajar dan Yulianto Achmad. (2017). Dualisme Penelitian Hukum Normatif E Empiri. Yogyakarta: Pustaka Pelajar. 
Peter Mahmud Marzuki. (2011). Penelitian Hukum. Jakarta: Prenadamedia.

Paulus Hadisuprapto. (2016). Juvenile Delinquency: Pemahaman dan Penangunangannya, Bandung: PT. Citra Aditya Bakti.

Ronny Hanitijo Soemitro. (1995). Metodologi Penelitian Hukum dan Jurimetri. Jakarta: Ghalia Indonesia.

Soerjono Soekanto. (2012). Pengantar Penelitian Hukum. Jakarta: UI Press.

Soetandyo Wignjosoebroto. (2013). Hukum Konsep dan Metode. Malang: Setara Press.

Sudarsono. (2015). Kenakalan Remaja: Prevensi, Rehabilitasi, dan Resosialisasi. Jakarta: Rineka Cipta.

\section{Artikel Jurnal}

Catherine D. Marcum. (2009). George E. Higgins, Examining the Effectiveness of Academic Scholarship on the Fight Against Cyberbullying and Cyberstalking, American Journal of Criminal Justice, Vol.11, No.2.

Richard Donegan, 2012, “Bullying and Cyberbullying: History, Statistics, Law, Prevention and Analysis", The Elon Journal of Undergraduate Research in Communications, 1(3).

Sameer Hinduja, Justin W. Patchin. 2008. Cyberbullying: An Exploratory Analysis of Factors Related to Offending And Victimization. Deviant Behavior. Vol.11, No.3.

Publikasi Instansi:

Asosiasi Penyelenggara Jasa Internet Indonesia (APJII), “Laporan Survei Penetrasi \& Profil Prilaku Pengguna Internet Indonesia," Polling Indonesia, (April, 2019). Reno Mardina. (2019). Kekerasan Terhadap Anak dan Remaja. Infodatin, (Juni, 2019).

\section{Internet}

Wikipedia, (2019), Daftar Negara Menurut Jumlah Pengguna Internet, Available online from: https://id.wikipedia.org/wiki/Daftar_negara_menurut_jumlah_pengguna_Int ernet, . [Accessed October 17, 2019]. 